\title{
City Gas Pipeline Routing Optimization Considering Cultural Heritage and Catastrophic Risk
}

\author{
Farizal F ${ }^{*}$, Muhammad Dachyar ${ }^{1}$, Yunita Prasetya ${ }^{1}$ \\ ${ }^{1}$ Department of Industrial Engineering, Faculty of Engineering, Universitas Indonesia, Kampus UI Depok, \\ Depok 16424, Indonesia
}

\begin{abstract}
To fulfill energy needs, especially of industrial and household sectors, natural gas is more desirable since Indonesia has abundant gas and it is more environmentally friendly. The better way to deliver the gas to consumers' sites is to use a pipeline. One important consideration in pipeline construction is route selection. This study aims to obtain the optimal gas pipeline route that has minimum investment cost while being able to serve as many consumers as possible within the available gas supply and at the same time reliable (having small catastrophic risks) and being able to conserve local cultural heritage. To this end, a mathematical model has been developed and solved. As a result, among three scenarios, the best route is scenario 3 , avoiding the populated area scenario. Its total investment cost is $1,331,016,661,674.34$ IDR with a pipeline length of $352.95 \mathrm{~km}$, a gas supply flow rate of 6.87 MMSCFD, and a total catastrophic cost of 198,039,407,500.00 IDR. The route passes 2 subdistricts with industrial areas and 71 subdistricts with household gas consumers. None of the subdistricts with cultural heritage sites are selected.
\end{abstract}

Keywords: Catastrophic cost; City gas routing; Cultural heritage; Optimization; Total investment cost

\section{Introduction}

The energy supply of Indonesia's industrial sector is still dominated by fossil energy, i.e., coal and natural gas. In 2018, the use of coal and natural gas reached $34.53 \%$ and $32.70 \%$, respectively. Meanwhile, in the same year, $48.22 \%$ of household energy needs were fulfilled by liquified petroleum gas (LPG) (ESDM, 2018). Natural gas can be used to fulfill the energy needs of industrial and household sectors. Fulfilling industry needs with gas can be done by converting industrial boilers or heaters to gas fuel boilers (Palomino and Nebra, 2012). For the household sector, converting LPG to natural gas saves consumer expenses by $30 \%$ per MMBtu (ESDM, nd).

Indonesia has abundant natural gas reserves; estimated up to 77.29 trillion standard cubic feet (TSCF) (ESDM, 2018). Natural gas is a flexible source since it can be stored and transported in the form of liquified natural gas, medium-conditioned liquified gas, or compressed natural gas using trucks or tankers (Ríoz-Mercado and Borraz-Sánches, 2015). However, large quantities of natural gas are more economical if it is transported through pipelines (Mikolajková-Alifov et al., 2019). The Indonesian government has established a master plan for the national natural gas distribution network through pipelines. The 
problem is that pipelines passing through many routes will increase investment costs.

Many studies on gas pipeline route determination have been done. Using the analytical hierarchy process method, Yildirim et al. (2017) examined factors that must be considered in selecting pipeline routes. Bawono and Kusrini (2017) studied the impact of investment schemes on city gas selling prices. Marcoulaki et al. (2012) developed a nonlinear programming model to determine the optimal pipeline route with data obtained from geographic information systems. The model was solved by the simulated annealing algorithm. Meanwhile, Sanaye and Mahmoudimehr (2013) proposed a mixed-integer nonlinear programming (MINLP) model for pipeline route selection by minimizing the total investment cost and gas pipeline operation with a minimum spanning tree (MST) and nonMST topology. Hong et al. (2019) used the MINLP model that was solved by the ant colony optimization algorithm to optimize pipeline routes with minimum construction costs. Maliki and Farizal (2019) determined pipeline routes taking into consideration environmental aspects using goal programming. Their model was solved with genetic algorithm (GA). Zarei and Amin-Naseri (2019) concluded that operating cost was the major part in the supply chain cost of the city gas network. Cornelis and Farizal (2020) developed a model that combined gas routing and plant location. Routing is also an important issue in distributing products (Sitompul and Horas, 2021). However, most models are still focused on the cost of pipes and compressors. A more comprehensive study that takes into consideration more factors that influence pipeline routing determination is needed.

This study aims to determine the optimal gas pipeline route, taking into consideration not only investment costs but also death risk costs, gas supply availability, and cultural heritage in a single integrated model. The proposed model considers industrial and household consumers simultaneously.

\section{Methods}

This study discusses the optimization of gas pipeline routes that have a minimum cost by considering various factors, including risks and preserving cultural heritage. For this purpose, the problem being considered is translated into a mathematical model. To solve the problem, data on the variables and parameters used in the model are collected. The data include the number of subdistricts in the considered city, the subdistrict area, population density, height of the land, number of permanent buildings, and cultural heritage sites in the subdistricts. Information on the target length of the pipeline and the distribution plan of the gas supply is also collected.

Calculation of the data and coding of optimization programs were developed using Python 3.8. Before the program was run, the coding was validated using a trial problem. Validation is granted if program calculation results are the same as manual calculations. The proposed model is run for three different settings: business as usual (BaU), relaxing cultural heritage scenario, and avoiding populated area scenario.

\subsection{Proposed Mathematical Model}

Decision variables;

$x_{i j}^{k}=$ segment of route from $i$ to $j$ for consumer $k ; x_{i j}^{k} \begin{cases}1, & \text { if selected } \\ 0, & \text { otherwise }\end{cases}$

$i$ : index for subdistrict $i=0,1,2,3, \ldots, p$

$j:$ index for subdistrict $j=0,1,2,3, \ldots, q$

$k$ : index for the type of consumer $k=1,2, \ldots, r$

Parameters;

$L_{i j}^{k} \quad$ : length of pipe from subdistrict $i$ to subdistrict $j$ for the type of gas consumer $k$ 
$C_{i n v_{i j}}^{k}$ : total investment cost from subdistrict $i$ to subdistrict $j$ for the type of gas consumer $k$

$C_{c a t}{ }_{i j}$ : total catastrophic cost from subdistrict $i$ to subdistrict $j$ for the type of gas consumer $k$

$G_{i j}^{k} \quad$ : gas demand from subdistrict $i$ to subdistrict $j$ for the type of gas consumer $k$

$A_{i j}^{k} \quad$ : cultural heritage from subdistrict $i$ to subdistrict $j$ for the type of gas consumer $k$

The proposed complete model:

$$
\text { Minimize } Z=\sum_{i=1}^{p} \sum_{j=1}^{q} \sum_{k=1}^{r} C_{i n v}^{k} \cdot x_{i j}^{k}
$$

Subject to:

$$
\begin{aligned}
& \sum_{i=1}^{p} \sum_{j=1}^{q} \sum_{k=1}^{r} C_{\text {cat }_{i j}}^{k} \cdot x_{i j}^{k} \leq C_{\text {catmax }} \\
& \sum_{i=1}^{p} \sum_{j=1}^{q} \sum_{k=1}^{r} L_{i j}^{k} \cdot x_{i j}^{k} \leq L_{\max } \\
& \sum_{i=1}^{p} \sum_{j=1}^{q} \sum_{k=1}^{r} A_{i j}^{k} \cdot x_{i j}^{k}=0 \\
& \sum_{i=1}^{p} \sum_{j=1}^{q} \sum_{k=1}^{r} G_{i j}^{k} \cdot x_{i j}^{k} \leq G_{\max } \\
& G_{i j}^{k} \cdot x_{i j}^{k} \geq G^{k} \text { for } \forall k \\
& \sum_{i=1}^{p} \sum_{j=1}^{q} \sum_{k=1}^{r} x_{i j}^{k}=1 \\
& x_{i j}^{k}\left\{\begin{array}{l}
1, \text { if selected } \\
0, \text { otherwise }
\end{array}\right.
\end{aligned}
$$

Notations $p$ and $q$ in indices $i$ and $j$ represent the number of subdistricts in the city. They start from 0 (represents the source of the subdistrict node) to $p$ or $q$ (represents the last sequence of the subdistrict node). Notation $k$ starts from 1 to 4 . $k=1$ represents the subdistrict without gas customer; $k=2,3$, and 4 represent the subdistrict with gas customer industrial type, the subdistrict with gas customer household type, and the subdistrict with both gas customer industrial and household types, respectively.

Equation 1 is the objective function of the model, which is to minimize the total investment cost of a selected segment of routes starting from the supply point to the last possible consumer (Menon, 2005). The valve station is used to open and close the faucet on the network. The valve plays an important role in maintenance, repair, and safety if leakage occurs. Every $8 \mathrm{~km}$ of pipe length requires 1 mainline valve station (MVS), and the cost of each MVS is $\$ 100,000$ (Menon, 2005). The pipe diameter is calculated using the Weymouth equation, as in Equation 9 (Crane, 1982):

$$
Q=432.7 \frac{T_{b}}{P_{b}}\left[\frac{P_{1}^{2}-P_{2}^{2}}{z_{\text {ave }} \cdot T_{\text {ave }} \cdot G . L}\right]^{\frac{1}{2}} \cdot D^{2.667}
$$

where $Q$ is the gas flow rate (SCFD), $T_{b}$ is the base temperature $\left({ }^{\circ} \mathrm{R}\right), T_{a v e}$ is the average temperature $\left({ }^{\circ} \mathrm{R}\right), Z_{\text {ave }}$ is the gas compressibility factor (dimensionless), $G$ is the specific gravity (dimensionless), $P_{b}$ is the base pressure (psia), $P_{1}$ is the upstream pressure (psia), and $P_{2}$ is the downstream pressure (psia).

Equations 2-8 of the model are constraints that rule how a segment of the route is selected. Equation 2 represents the total catastrophic cost limit. This constraint is the compensation cost that must be paid if an accident causes injury or death due to an explosion or leakage on the pipe connection. The value of $C_{\text {catmax }}$ is estimated as $738,949,705,750.00$ IDR. Government Regulation No. 82 Year of 2019 on the amendment of Government Regulation No. 44 Year of 2015 on the Implementation of Work Accident and Death Insurance Programs dictates that workers who are at risk of work accidents and death are entitled to compensation. The amount of compensation paid is comparable to the conditions experienced by workers. Compensation up to $22,000,000.00$ IDR is given as a 
lump sum to the family of the heirs. The catastrophic cost is estimated using Equations 10 and 11 (Ma et al., 2013):

$$
\begin{aligned}
& C_{c a t}=22,000,000.00 \cdot N_{i} \\
& N_{i}=\int \rho_{p} \cdot P_{i} \cdot d A_{i}
\end{aligned}
$$

where $C_{\text {cat }}$ is the catastrophic cost (IDR), $N_{i}$ is the estimated number of deaths (people), $\rho_{p}$ is the density of population (people $/ \mathrm{km}^{2}$ ), $P_{i}$ is the fatality rate, and $A_{i}$ is the total affected area $\left(\mathrm{km}^{2}\right)$.

Accidents on gas pipelines are usually caused by gas leakage due to a hole or crack. The leakage releases chemical substances that can cause poisoning, injuries, and even death due to heat radiation and large explosions. According to Zhou and Wu (2017), the leakage risk index in open areas is much smaller than in densely populated residential areas. This study emphasizes the impact of leakages that can lead to a large explosion. The explosion occurs when some of the leaked gas gathers in the air to form a vapor cloud and makes a contact with a fire source. When an explosion occurs, it can cause overpressure and generate a force that can damage the building. This is treacherous for people in the building. Hatmoko et al. (2021) identified 42 types of risk in construction projects.

Equation 3 is the total pipeline length constructed from the origin to the last spot of the route. The length is expressed in kilometers $(\mathrm{km})$. The pipe length constructed on a subdistrict is estimated as the perimeter of the subdistrict and calculated using Equations 12 and 13.

$$
\begin{aligned}
& D_{\text {sub }}=\sqrt{\frac{4 \cdot L_{\text {sub }}}{\pi}} \\
& K_{\text {sub }}=\pi \cdot D_{\text {sub }}
\end{aligned}
$$

where $D_{\text {sub }}$ is the diameter of the subdistrict $(\mathrm{km}), L_{s u b}$ is the total area of the subdistrict $\left(\mathrm{km}^{2}\right), K_{\text {sub }}$ is the perimeter of the subdistrict $(\mathrm{km})$, and $\pi$ is the ratio of the circumference to the diameter of any circle.

Equation 4 is about cultural heritage constraint. This equation is set equal to 0 , which means that any segment of route $x_{i j}^{k}$ that has cultural heritage on it will be unselected. According to Undang-Undang Republik Indonesia Nomor 11 Tahun 2010 (Law of the Republic of Indonesia Number 11 Year of 2010 on Cultural Conservation), cultural heritage is any cultural artifact (physical) in the form of cultural heritage object, cultural heritage building, cultural heritage structure, cultural heritage site, and cultural heritage area whether the object is on land and/or in water. Cultural heritage has to be protected. Its existence should be preserved because it has important values for history, science, education, religion, and/or culture.

Equation 5 is a constraint on the total gas supplied to the consumers. It should not exceed the available gas sent from the source. Equation 6 states that gas for the industry area should fulfill the gas demand of the area. Since natural gas for the industry is used to substitute its electricity, the demand is calculated based on the electricity consumed in the area. The household gas demand is calculated based on the amount of demand in one house multiplied by the number of permanent houses in the subdistrict. Furthermore, it is assumed that gas is needed until 2050. The projected consumptions until 2050 are calculated by following Meadows et al. (2004) using Equation 14. Equation 7 of the model is constrained to make sure that each route $x_{i j}^{k}$ is only selected one time; no repetition is allowed. The last equation, Equation 8, is a binary constraint to indicate non-negativity.

$$
P_{t}=P_{0}(1+i)^{n}
$$


where $P_{o}$ is the gas consumption per day (in MMSCFD), $i$ is the population growth rate of the city, and $n$ is the years' interval.

\subsection{Computer Program Verification and Validation}

To be able to solve a complex real problem, the proposed model is translated to a computer program using Python release 3.8 software. The ant colony algorithm is also coded on the program for the optimization solver tool. The ant colony algorithm is used since it gives a better optimal result than other algorithms (Christodoulou and Ellinas, 2010; Hong et al. 2019). The computer program is verified and validated if it runs well and produces a correct result. For this purpose, verification and validation of the program was conducted on a small-size trial problem. The manual calculation results for a trial problem are summarized in Table 1.

Table 1 Manual calculation results of route selection

\begin{tabular}{crccrc}
\hline Option & \multicolumn{1}{c}{$L_{i j}^{k}$} & $G_{i j}^{k}$ & $A_{i j}^{k}$ & \multicolumn{1}{c}{$C_{c a t}^{k}$} & \multicolumn{1}{c}{$C_{i n v_{i j}}^{k}$} \\
\hline 1 & 5.52 & 3.64 & 0 & $392,931,000$ & $20,673,216,950$ \\
2 & 10.37 & 0.03 & 0 & $2,076,228,000$ & $40,511,974,223$ \\
3 & 7.64 & 3.04 & 0 & $620,193,750$ & $30,308,792,954$ \\
4 & 18.09 & 0.04 & 0 & $3,177,396,750$ & $71,126,633,840$ \\
\hline
\end{tabular}

The computer program running results with Python 3.8 is shown in Figure 1. The results show that the routes are $4 \rightarrow 3 \rightarrow 2$ with an objective function of $71,126,633,840$.

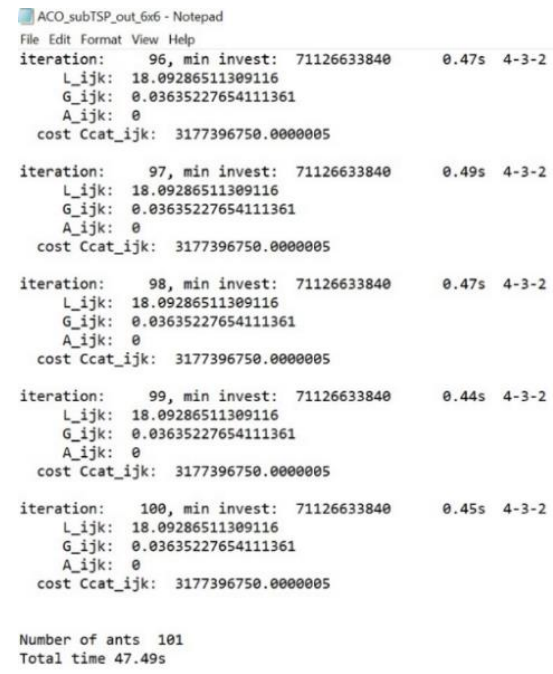

Figure 1 Computer trial problem results

Given that the computer program results are the same as manual calculation results, the computer program is verified and validated. The program is ready to be used to solve real complex problems.

\section{Results and Discussion}

\subsection{Case Study: Natural Gas Pipeline Routing at the City of Semarang}

The City of Semarang has an area of $373.70 \mathrm{~km}^{2}$ wide. It consists of 16 districts and 177 subdistricts. Semarang City is located between $6^{\circ} 50^{\prime}-7^{\circ} 10^{\prime}$ South Latitude and $109^{\circ} 35^{\prime}-$ $110^{\circ} 50^{\prime}$ East Longitude, with the northern boundary with the Java Sea, the east with Demak Regency, the west with Kendal Regency, and the south with Semarang Regency. The city's 
average temperature is $27^{\circ} \mathrm{C}$ (Profil Kota Semarang, 2018). The City of Semarang has many cultural heritages that need to be preserved. There are 41 cultural heritage sites located in several different subdistricts (DP Ruang, 2021). The city is taken as a case study since Semarang is mentioned in the master plan for the National Natural Gas Transmission and Distribution Network (DPMP, 2019).

\subsection{Data Collection and Parameter Calculation}

The source of gas supply for Central Java distribution is from the Cepu Block field, i.e., the Jembatan Tiung Biru gas field. The supply amount is 172 MMSCFD, and the allocation for Semarang City is 7.7 MMSCFD. To determine the Semarang City gas route, data collected include the number of subdistricts, list of cultural heritage sites (DP Ruang, 2021), list of industrial areas (DPMP, 2019), and the number of permanent buildings (BPS Kota Semarang, 2019). The total length of the pipe network is 1,377 km (Bappenas, 2018).

The parameters used in this study were calculated using Equations 9-14. The gas demand for industrial areas is calculated by converting the electricity demand of the area to natural gas units. The standard of electricity demand is set to $0.15-0.2 \mathrm{MW} / \mathrm{ha}$ (DPMP, 2019). The gas demand estimation for each industrial area is shown in Table 2.

Table 2 Gas demand of industrial areas

\begin{tabular}{cllccc}
\hline No. & Industrial area & Subdistrict & Area (ha) & $\begin{array}{c}\text { Power of electricity } \\
\text { (MW) }\end{array}$ & $\begin{array}{c}\text { Gas demand } \\
\text { (MMSCFD) }\end{array}$ \\
\hline 1 & Wijaya Kusuma & Randu Garut & 250 & 37.5 & 3.03 \\
2 & Tambak Aji & Tambak Aji & 130 & 19.5 & 1.58 \\
3 & Semarang Baru & Mijen & 250 & 37.5 & 3.03 \\
4 & Candi & Ngaliyan & 300 & 45 & 3.64 \\
5 & Terboyo & Terboyo Wetan & 300 & 45 & 3.64 \\
\hline \multicolumn{5}{c}{ Total } \\
\hline
\end{tabular}

\subsection{City of Semarang Gas Routing}

\section{$\underline{\text { 3.3.1. BaU Scenario }}$}

The computer program is run on the collected data, and the optimized route results for the BaU scenario are shown in Figure 2.

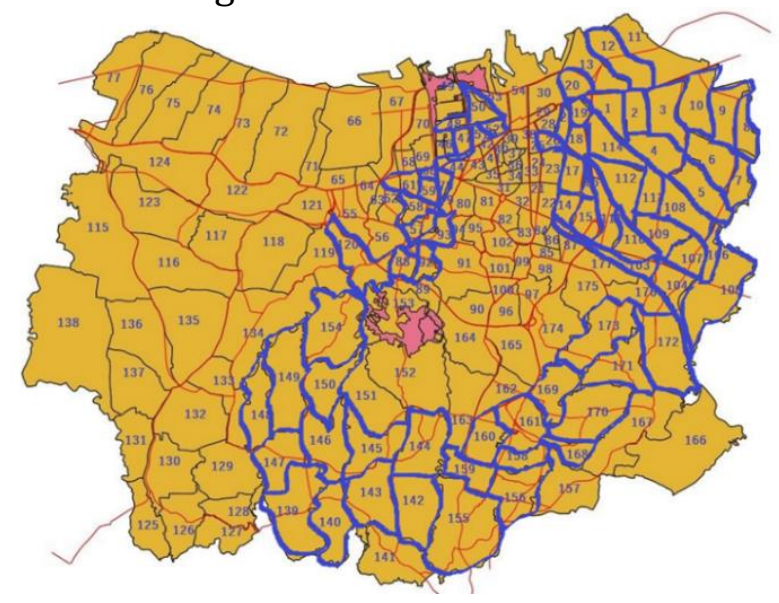

Figure 2 Optimal pipeline route of BaU scenario

The total investment cost of this scenario is $1,183,299,137,314.37$ IDR. This cost is the minimum investment cost to construct the pipeline network shown in Figure 4 (the blue color line) that fulfills the limitations of total pipe length, gas flow rate, and no cultural heritage subdistrict; i.e., pipe installation along $315.76 \mathrm{~km}$ with the total gas flow rate is 
6.54 MMSCFD (3.64 MMSCFD is allocated for Terboyo Wetan industrial estate subdistrict and the remaining 0.0034 MMSCFD is for household customers; gas that is distributed to the rest of the selected subdistricts is only used to meet household needs). The gas is distributed to 70 selected subdistricts that have different population densities. For instance, Tlogosari Kulon, Muktiharjo Kidul, and Sendangmulyo have population densities of $11,691,16,403$, and 8,209 people $/ \mathrm{km}^{2}$, respectively. The selected route shown in Figure 4 has no subdistrict with cultural heritage sites. Figure 3 clearly shows that the selected route mainly covered the eastern and southern parts of the city.

\subsubsection{Scenario 2}

Scenario 2 is a setting where subdistricts with cultural heritage sites are allowed to be selected. This scenario is possible since subdistricts with cultural heritage sites are close by or adjacent to the ones with no cultural heritage sites.

The optimized routing result for this scenario is depicted in Figure 3. Its total investment cost is $903,509,890,871.73$ IDR. The total pipeline length is $237.92 \mathrm{~km}$, and the total gas flow rate is 2.61 MMSCFD. The gas is entirely used to meet household gas needs in the area since no subdistricts with industrial centers are selected. The selected subdistricts to get gas are located in the north and east regions of the city. Table 3 summarizes subdistricts with cultural heritage sites that have been selected to get gas.

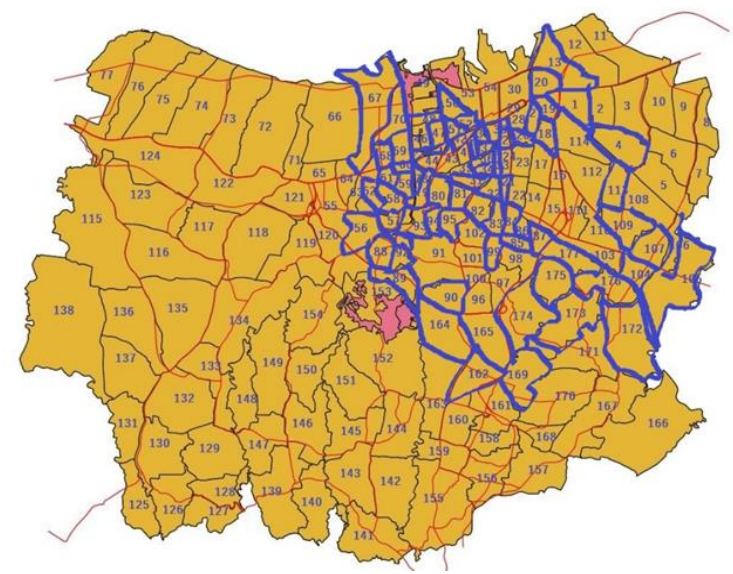

Figure 3 Optimal pipeline route of scenario 2

Table 3 Summary of subdistricts with cultural heritage sites passed by the pipeline route

\begin{tabular}{ll}
\hline \multicolumn{1}{c}{ Subdistrict } & \multicolumn{1}{c}{ Cultural heritage sites } \\
\hline Kebon Agung & Primkopal \\
Pekunden & Kantor Suara Merdeka, Pasar Johar, SMA Theresiana \\
Brumbungan & Gedung Marba \\
Purwodinatan & Kantor Urusan Piutang Negara, Bank Niaga, Bank Mandiri, PT Borssumijwehry, \\
& Asuran Timur Jauh \\
Kauman & Kantor Telephone Pasar Johar \\
Bangunharjo & Masjid Kauman \\
Kembangsari & Bangunan ex-hotel Dibya Putri \\
Barusari & Musium Mandala \\
Randusari & Gereja Katedral, RS Kariadi, Gereja Aloysius \\
Mugasari & SMA Negeri 1 Semarang \\
Bendungan & Hotel Candibaru, Leutenant Governor Mansion \\
\hline
\end{tabular}

\subsubsection{Scenario 3}

Scenario 3 is a scenario to avoid high fatality loss. The scenario is achieved by constructing the pipeline passing lesser-density population subdistricts. Of 177 Semarang's subdistricts, 88 have been identified as high-density-populated subdistricts. 
As a result, 73 subdistricts were selected to receive gas with routing, as shown in Figure 4. Its total investment cost is 1,331,016,661,674.34 IDR. The cost is used to build a route of $352.95 \mathrm{~km}$ in length.

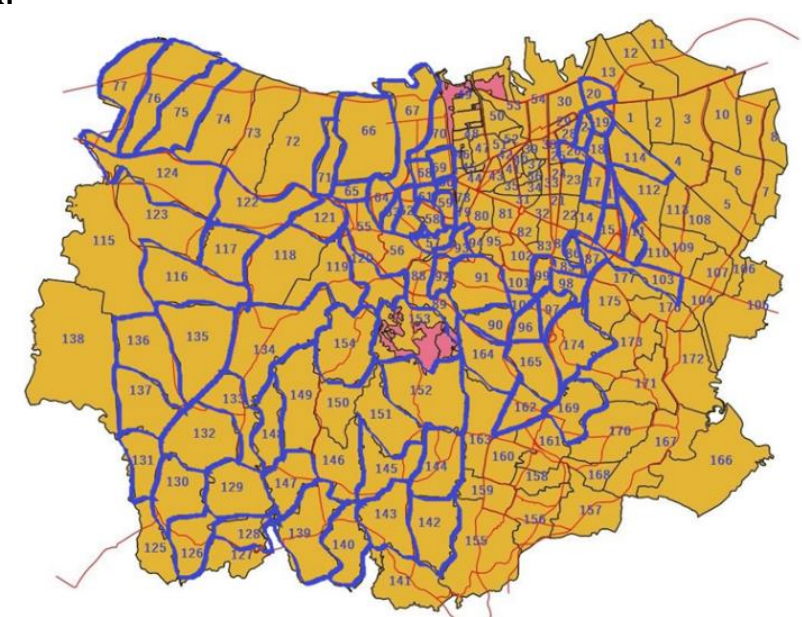

Figure 4 Optimal pipeline route of scenario 3

The total gas flow rate for this scenario is 6.87 MMSCFD, where 3.05 MMSCFD are distributed to the Mijen subdistrict to meet the need of 3.03 MMSCFD gas for the Bukit Semarang Baru industrial area and 0.018 MMSCFD for households in the subdistrict and 1.61 MMSCFD are sent to the Tambakaji subdistrict to meet the need of 1.58 MMSCFD for the Tambak Aji industrial area and 0.03 MMSCFD for households in the subdistrict. While the rest are entirely used to meet household gas needs in the selected subdistricts, Figures 2-4 show that this scenario more evenly covers the Semarang subdistricts than scenario 2 and the BaU scenario. No subdistricts with cultural heritage sites have been selected.

\section{Conclusions}

The three scenario results show that the proposed mathematical model is applicable for use as an alternative tool for the City of Semarang gas route determination. For Semarang, among the three scenarios run in this study, the third scenario is the best option. This scenario provides more subdistricts access to gas with reasonable investment costs and risks. At the same time, the route selected preserves the cultural heritage of the city.

The model can be duplicated to determine city gas routing for other cities, given that the data needed are available. Depending on the goal to be achieved, city decision-makers can use the BaU scenario, scenario 2, or scenario 3 to determine suitable gas routes to meet their city needs.

The proposed model has simplified the problem that the gas flow is assumed in the steady state and the city's topology is assumed linear. Also, this study used only the ant colony algorithm. To make the model more realistic, future research may address these two issues as well as comparing various heuristic algorithms.

\section{References}

Bappenas, 2018. Rencana Kerja Pemerintah Tahun 2019 (Government Work Plan for 2019). Badan Perencanaan Pembangunan Nasional (National Development Planning Agency), Jakarta, Indonesia. Available Online at https://www.bappenas.go.id/files/rkp/PEMUTAKHIRAN\%20RKP\%20TAHUN\%2020 19.pdf, Accessed on October 18, 2020 
Bawono, A.A., Kusrini, E., 2017. The Impacts of Financing Investment Scenarios on PipedNatural Gas Prices (GPs) for Households in Indonesia. International Journal of Technology, Volume 8(8), pp. 1402-1413

BPS Kota Semarang, 2019. Kota Semarang Dalam Angka 2019 (Semarang City in 2019 Figures). Badan Pusat Statistik Semarang (Central Bureau of Statistics of Semarang), Semarang, Indonesia. Available Online at https://semarangkota.bps.go.id/publication/2019/08/16/be2163d8fad5db43670a6 dd5/kota-semarang-dalam-angka-2019.html, Accessed on February 9, 2021

Christodoulou, S.E., Ellinas, G., 2010. Pipe Routing Through Ant Colony Optimization. Journal of Infrastructure Systems, Volume 16(2), https://doi.org/http://dx.doi.org/10.1061/(ASCE)1076-0342(2010)16:2(149)

Cornelis, C.I., Farizal, 2020. Two-Step Optimization of Natural Gas Power Generation Location and Pipe Supply System. In: AIP Conference Proceedings, Volume 2230, p. 050008

Crane, 1982. Flow of Fluids through Valves, Fittings, and Pipe. Technical Paper No. 410M, Crane Co, New York, NY

DPMP, 2019. Perencanaan Penyediaan Infrastruktur Pendukung Industri di Kawasan Jawa Tengah (Planning for the Provision of Industrial Supporting Infrastructure in the Central Java Region). Dinas Penanaman Modal dan Pelayanan Terpadu Satu Pintu Kota Semarang (Semarang City Investment and One-Stop Integrated Service Office), Semarang, Indonesia. Available Online at https://web.dpmptsp.jatengprov.go.id/packages/upload/portal/files/PERENCANAA N\%20PENYEDIAAN\%20INFRASTRUKTUR\%20PENDUKUNG.pdf, Accessed on February 15, 2021

DP Ruang, 2021. Bangunan Cagar Budaya (Cultural Heritage Building), Dinas Penataan Ruang Kota Semarang (Semarang City Spatial Planning Service), Semarang, Indonesia. Available Online at http://satudata.semarangkota.go.id/adm/file/20180426104140BangunanCagarBud aya1.pdf, Accessed on February 15, 2021

ESDM, 2018. Handbook of Energy \& Economic Statistics. Kementerian Energi dan Sumber Daya Mineral (Ministry of Energy and Mineral Resources), Jakarta, Indonesia. Available Online at https://www.esdm.go.id/assets/media/content/content-indonesia-energyoutlook-2019-english-version.pdf, Accessed on October 18, 2020

ESDM, nd. Pembangunan Jaringan Gas Bumi Untuk Rumah Tangga (Construction of Natural Gas Network for Households). Kementerian Energi dan Sumber Daya Mineral (Ministry of Energy and Mineral Resources), Jakarta, Indonesia. Available Online at https://migas.esdm.go.id/uploads/buku-jasrgas-isi.pdf, Accessed on_October 18, 2020

Hatmoko, J.U.D., Astuti, P.K., Farania, S.N., 2021. Insuring Project Risks: Contractor Expectations versus Insurance Company Policies. International Journal of Technology, Volume 12(1), pp. 90-100

Hong, B., Li, X., Di, G., Li, Y., Liu, X., Chen, S., Gong, J., 2019. An Integrated MILP Method for Gathering Pipeline Networks Considering Hydraulic Characteristics. Chemical Engineering Research and Design, Volume 152, pp. 320-335

Ma, L., Cheng, L., Li, M., 2013. Quantitative Risk Analysis of Urban Natural Gas Pipeline Networks using Geographical Information Systems. Journal of Loss Prevention in the Process Industries, Volume 26(6), pp. 1183-1192

Maliki, S., Farizal, 2019. Optimization of Gas Pipeline Route Selection with Goal Programming Considering Environmental Aspects. In: Proceeding of $1^{\text {st }}$ GCC 
International Conference on Industrial Engineering and Operations Management, IEOM, Riyadh, Saudi Arabia

Marcoulaki, E.C., Papazoglou, I.A., Pixopoulou, N., 2012. Integrated Framework for the Design of Pipeline Systems using Stochastic Optimisation and GIS Tools. Chemical Engineering Research and Design, Volume 90(12), pp. 2209-2222

Meadows, D., Randers, J., Meadows, D., 2004. The Limits to Growth: The 30-Year Update. Chelsea Green Publishing, Chelsea, VT

Menon, E.S., 2005. Gas Pipeline Hydraulics. CRC Press, Boca Raton, FL

Mikolajková-Alifov, M., Pettersson, F., Björklund-Sänkiaho, M., Saxén,H.A., 2019. Model of Optimal Gas Supply to a Set of Distributed Consumers. Energies, Volume 12(3), pp. 127

Palomino, R.G., Nebra, S.A., 2012. The Potential of Natural Gas Use Including Cogeneration in Large-Sized Industry and Commercial Sector in Peru. Energy Policy, Volume 50, pp. 192-206

Profil Kota Semarang, 2018. Variety of Culture. Available Online at http://semarangkota.go.id/p/33/profil_kota, Accessed on May 6, 2021

Ríoz-Mercado, R.Z., Borraz-Sánchez, C., 2015. Optimization Problems in Natural Gas Transportation Systems: A State-of-the-Art Review. Applied Energy, Volume 147, pp. 536-555

Sanaye, S., Mahmoudimehr, J., 2013. Optimal Design of a Natural Gas Transmission Network Layout. Chemical Engineering Research and Design, Volume 91(12), pp. 2465-2476

Sitompul, C., Horas, O.M., 2021. A Vehicle Routing Problem with Time Windows Subject to the Constraint of Vehicles and Good's Dimensions. International Journal of Technology, Volume 12(4), pp. 865-875

Yildirim, V., Yomralioglu, T., Nisanci, R., Çolak, H.E., Bediroğlu, S., Saralioglu, E.A., 2017. A Spatial Multicriteria Decision-Making Method for Natural Gas Transmission Pipeline Routing. Structure and Infrastructure Engineering, Volume 13(5), pp. 567-580

Zarei, J., Amin-Naseri, M.R., 2019. An Integrated Optimization Model for Natural Gas Supply Chain. Energy, Volume 185, pp. 1114-1130

Zhou, Y., Wu, Z., 2017. Risk Index Assessment for Urban Natural Gas Pipeline Leakage based on Artificial Neural Network. In: The $13^{\text {th }}$ International Conference on Natural Computation, Fuzzy Systems and Knowledge Discovery (ICNC-FSKD), 29-31 July 